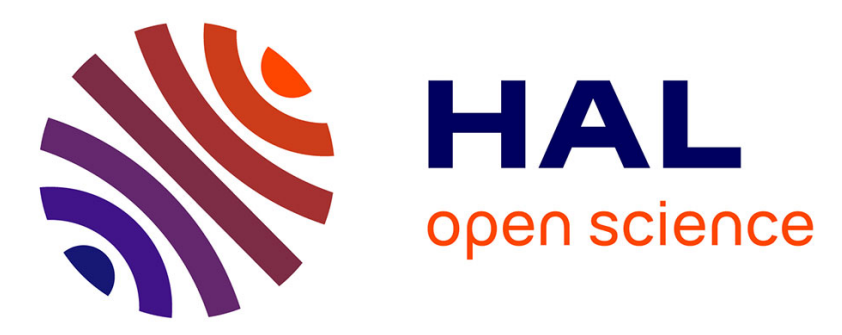

\title{
MALDI-TOF-MS for rapid detection of staphylococcal Panton-Valentine leukocidin
}

Fadi Bittar, Zoulikha Ouchenane, Farida Smati, Didier Raoult, Jean-Marc Rolain

\section{- To cite this version:}

Fadi Bittar, Zoulikha Ouchenane, Farida Smati, Didier Raoult, Jean-Marc Rolain. MALDI-TOF-MS for rapid detection of staphylococcal Panton-Valentine leukocidin. International Journal of Antimicrobial Agents, 2009, 34 (5), pp.467. 10.1016/j.ijantimicag.2009.03.017 . hal-00556340

\section{HAL Id: hal-00556340 https://hal.science/hal-00556340}

Submitted on 16 Jan 2011

HAL is a multi-disciplinary open access archive for the deposit and dissemination of scientific research documents, whether they are published or not. The documents may come from teaching and research institutions in France or abroad, or from public or private research centers.
L'archive ouverte pluridisciplinaire HAL, est destinée au dépôt et à la diffusion de documents scientifiques de niveau recherche, publiés ou non, émanant des établissements d'enseignement et de recherche français ou étrangers, des laboratoires publics ou privés. 


\section{Accepted Manuscript}

Title: MALDI-TOF-MS for rapid detection of staphylococcal

Panton-Valentine leukocidin

Authors: Fadi Bittar, Zoulikha Ouchenane, Farida Smati,

Didier Raoult, Jean-Marc Rolain

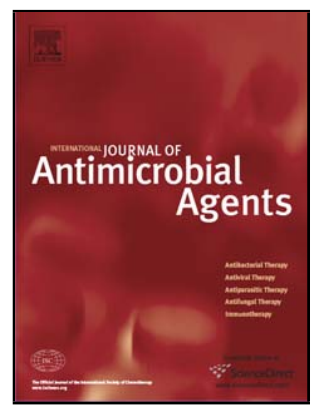

PII:

S0924-8579(09)00150-2

DOI: doi:10.1016/j.ijantimicag.2009.03.017

Reference: ANTAGE 3022

To appear in:

International Journal

of

Antimicrobial

Agents

Received date: $\quad$ 20-3-2009

Revised date: $\quad$ 24-3-2009

Accepted date: $\quad$ 24-3-2009

Please cite this article as: Bittar F, Ouchenane Z, Smati F, Raoult D, Rolain J-M, MALDI-TOF-MS for rapid detection of staphylococcal Panton-Valentine leukocidin, International Journal of Antimicrobial Agents (2008), doi:10.1016/j.ijantimicag.2009.03.017

This is a PDF file of an unedited manuscript that has been accepted for publication. As a service to our customers we are providing this early version of the manuscript. The manuscript will undergo copyediting, typesetting, and review of the resulting proof before it is published in its final form. Please note that during the production process errors may be discovered which could affect the content, and all legal disclaimers that apply to the journal pertain. 


\section{MALDI-TOF-MS for rapid detection of staphylococcal Panton- Valentine leukocidin}

Fadi Bittar ${ }^{\mathrm{a}}$, Zoulikha Ouchenane ${ }^{\mathrm{b}}$, Farida Smati ${ }^{\mathrm{b}}$, Didier Raoult ${ }^{\mathrm{a}}$, Jean-Marc Rolain $^{\mathrm{a}, *}$

a Unité de Recherche sur les Maladies Infectieuses et Tropicales Emergentes (URMITE), CNRS-IRD, UMR 6236, Faculté de Médecine et de Pharmacie, Université de la Méditerranée, 27 Bd Jean Moulin, 13385 Marseille Cedex 05, France

${ }^{\mathrm{b}}$ Laboratoire de Bacteriologie, Hôpital Militaire Universitaire de Constantine, Algeria

Received 20 March 2009; accepted 24 March 2009

Keywords: Staphylococcus aureus; Panton-Valentine leukocidin; Mass spectrometry; Toxin production; Virulence factor

* Corresponding author. Tel.: +33 4913243 75; fax: +33491387772.

E-mail address: jean-marc.rolain@univmed.fr (J.-M. Rolain). 


\section{Abstract}

Toxin-producing Gram-positive bacteria are responsible for emerging and lifethreatening infections in humans worldwide. Both rapid toxin detection and adapted therapy are essential to limit the morbidity due to such toxins, especially staphylococcal Panton-Valentine leukocidin (PVL). Here we describe the use of a mass spectrometry profile generated by matrix-assisted laser desorption/ionisation time-of-flight (MALDI-TOF) followed by ClinProTools ${ }^{T M} 2.0$ software analysis to find a reproducible model able to identify PVL in Staphylococcus aureus strains. Eighty-one S. aureus strains were used and tested for the presence of PVL, toxic shock syndrome toxin (TSST-1) and mecA genes. The peak at 4448 mass-to-charge ratio $(\mathrm{m} / \mathrm{z})$ was the most relevant peak to differentiate between PVL-producing and nonPVL-producing S. aureus. A model using only this peak had an overall recognition capability of $100 \%$ and an overall cross-validation of $77.07 \%$. Prospective evaluation of the model allowed two cases of PVL-producing strains to be detected within a few minutes during the time of care and before polymerase chain reaction (PCR) results. Our study represents a proof of concept for the use of such rapid technology as a point-of-care method to identify potential lethal toxin quickly. We believe that such a rapid method will be timely to help change the therapeutic strategy and could be used in the future for other pathogens and infectious diseases. 


\section{Introduction}

Serious complications caused by Staphylococcus aureus, one of the most significant and frequent human pathogens, are a worldwide phenomenon that concern both hospital and community settings. Toxin production contributes mainly to the pathogenicity of this bacterium. Panton-Valentine leukocidin (PVL), a twocomponent, pore-forming, cytolytic toxin that targets polymorphonuclear cells and causes cell death by necrosis or apoptosis [1], is one of the most virulent staphylococcal toxins described. Necrotizing pneumonia [2] and necrotizing skin and soft tissue infection [3] are the predominant results due to infection by PVL-producing S. aureus strains. Because severe infection caused by strains producing PVL should benefit from a quickly adapted therapy [4] in order to decrease mortality, rapid detection of this toxin is critical.

Classical approaches for recognising PVL toxin are generally based on the immunological properties of the toxin, such as enzyme-linked immunosorbent assay (ELISA) [5] and latex agglutination [6], or on polymerase chain reaction (PCR)-based methods [7]. These assays are costly and time-consuming methods. Recently, matrix-assisted laser desorption/ionisation time-of-flight mass spectrometry (MALDITOF-MS) has played an interesting role in microbiological laboratories owing to its speed, ease of use and accuracy in the identification and classification of bacteria, including S. aureus [8], as well as its discriminatory power to differentiate between strains with different phenotypes, including the expression of antibiotic resistance $[9,10]$. 
This work provides a proof of concept that the spectra profiling generated by MALDITOF-MS could be used as a clinical microbiology strategy to identify quickly $S$. aureus isolates harbouring PVL toxin and thus to adapt therapy during the time of care of the patient.

\section{Material and methods}

\subsection{Bacterial strains}

Study strains comprised 81 S. aureus isolated from patients either at Hôpital Militaire Universitaire de Constantine, Algeria, between January 2005 and March 2007 (64 strains) or at Timone Hospital in Marseille, France (17 strains). An additional 34 S. aureus strains from Timone Hospital were also used prospectively for external validation. The isolates were recovered from different pathology samples. The clinical sources of the different strains are summarised in Table 1.

\subsection{Identification of Staphylococcus aureus}

The isolates were first identified by conventional methods including Gram staining, catalase activity, mannitol fermentation, ability to coagulate rabbit plasma (bioMérieux, Marcy l'Etoile, France) and Pastorex Staph-Plus agglutination (bioMérieux). The identification was confirmed using the VITEK 2 Auto System (bioMérieux). Antimicrobial susceptibility testing was performed by the disk diffusion method according to the Clinical and Laboratory Standards Institute and also using VITEK 2. 


\subsection{Detection of the mecA gene PVL toxin and SCCmec typing}

To confirm resistance to meticillin in $S$. aureus isolates, the primers mecAF (5'GTTAGATTGGGATCATAGCGTCATT) and mecAR (5'TGCCTAATCTCATATGTGTTCCTGTAT) and the TaqMan probe mecAProbe (6FAM-TTCCAGGAATGCAGAAAGACCAAAGCAT-TAMRA) were used in this study.

Staphylococcal cassette chromosome mec (SCCmec) typing was performed as described previously [7]. For SCCmec type V, the following primers and TaqMan probe were used: cassMecVF (5'-TCTGGGAGTTCTGCCTGTCA); cassMecVR (5'TCACATTTGACGCAATCTGCT); and cassMecVP (6FAMTGCTGAAGTCGTCGAACGCGTAATCA-TAMRA).

All isolates were also screened by real-time PCR for the presence of PVL toxin and toxic shock syndrome toxin (TSST-1) using the primers and TaqMan probe as described previously $[7,11]$.

\subsection{Bacterial analysis using MALDI-TOF-MS}

Strains were plated on Columbia agar with $5 \%$ sheep blood (bioMérieux) and incubated for $24 \mathrm{~h}$ at $37^{\circ} \mathrm{C}$. One colony from each strain was harvested and deposited on a target plate (Bruker Daltonics, Bremen, Germany) in three or four replicates to minimise random effect. Two microlitres of matrix solution (saturated $\alpha$ cyano-4-hydroxycinnamic acid, 50\% acetonitrile, $2.5 \%$ trifluoroacetic acid) was then added and allowed to co-crystallise with the sample. Analysis was performed in an MALDI-TOF-MS spectrometer (337 nm) (Autoflex; Bruker Daltonics) with the FLEX control software (Bruker Daltonics). Positives ions were extracted with an 
accelerating voltage of $20 \mathrm{kV}$ in linear mode. The spectra were analysed in a massto-charge ratio $(\mathrm{m} / \mathrm{z})$ range of 2000 to 20000 . The profiles were compared and analysed using BioTyper 2.0 software and finally mass spectrometric data were analysed using ClinProTools ${ }^{\mathrm{TM}} 2.0$ to find PVL biomarker candidates. Generating the classification model in ClinProTools ${ }^{\mathrm{TM}} 2.0$ was performed using Genetic Algorithm. Recognition capability and cross-validation (i.e. the measure of the reliability used to predict the accuracy of the model) were calculated by the software with percentage values. External validation was carried out using 34 strains collected at Timone Hospital in Marseille in a blinded fashion. A $P$-value of $<0.05$ was considered statistically significant.

\section{Results}

All the isolates included in the study were first tested for the presence of PVL, TSST1 and mecA genes as well as determination of SCCmec type. Table 1 presents the results of the different PCRs obtained from the $81 \mathrm{~S}$. aureus strains. The following different isolate types were found in the collection: $\mathrm{PVL}^{+}$mecA $\mathrm{A}^{+} \mathrm{S}$. aureus $(n=20)$; $\mathrm{PVL}^{+}$mecA $A^{-}$. aureus $(n=4) ; \mathrm{TSST}^{-} 1^{+} \operatorname{mec}^{+} \mathrm{S}$. aureus $(n=1) ; \mathrm{TSST}^{-}{ }^{+}$mecA $^{-} \mathrm{S}$. aureus $(n=4)$; $m e c A^{+} S$. aureus $(n=47)$; and $m e c A^{-} S$. aureus $(n=5)$.

First we compared the MALDI-TOF spectra obtained from strains harbouring the PVL gene (24 isolates) with the spectra obtained from the other $S$. aureus (57 isolates) using ClinProTools ${ }^{\mathrm{TM}}$ 2.0. Using Genetic Algorithm analysis, several models with a different number of peaks have been generated. Considering the $P$-value and standard deviation given by the software, many peaks were differentially expressed between the two groups. Two interesting peaks were $4448 \mathrm{~m} / \mathrm{z}$ and $5302 \mathrm{~m} / \mathrm{z}$, which 
were found repeatedly to be used by the software. Forcing these two selected peaks into a model of two peaks allowed $\mathrm{PVL}^{+}$and $\mathrm{PVL}^{-}$strains to be distinguished with a recognition capability of $100 \%$ (100\% for $\mathrm{PVL}^{+}$and $100 \%$ for $\left.\mathrm{PVL}^{-}\right)$and crossvalidation of $83.51 \%$ (77.91\% for $\mathrm{PVL}^{+}$and $89.1 \%$ for $\left.\mathrm{PVL}^{-}\right)$. We then searched for the presence or absence of these two selected peaks in the spectra of the different studied strains. Fig. 1 presents an example of the presence and absence of the 4448 $\mathrm{m} / \mathrm{z}$ peak in a $\mathrm{PVL}^{+}$and a $\mathrm{PVL}^{-}$strain, respectively. The $4448 \mathrm{~m} / \mathrm{z}$ peak exhibited a sensitivity of $83.33 \%$, a specificity of $98.25 \%$, a positive predictive value (PPV) of 95.24\% and a negative predictive value (NPV) of $93.33 \%$. Only one of $57 \mathrm{PVL}^{-}$ strains had this peak, whereas 4 of $24 \mathrm{PVL}^{+}$strains did not. The $5302 \mathrm{~m} / \mathrm{z}$ peak yielded a sensitivity of $100 \%$, a specificity of $56.14 \%$, a PPV of $48.98 \%$ and NPV of $100 \%$. Thus, the $4448 \mathrm{~m} / \mathrm{z}$ peak was the most relevant peak to separate the two groups (Fig. 2). Interestingly, a model using only the $4448 \mathrm{~m} / \mathrm{z}$ peak had a recognition capability of $100 \%$ (100\% for $\mathrm{PVL}^{+}$and $100 \%$ for $\left.\mathrm{PVL}^{-}\right)$and crossvalidation of $77.07 \%\left(67.48 \%\right.$ for $\mathrm{PVL}^{+}$and $86.65 \%$ for $\left.\mathrm{PVL}^{-}\right)$.

Finally, the latest model (i.e. the model with the $4448 \mathrm{~m} / \mathrm{z}$ peak only) was evaluated blindly using 34 clinical $S$. aureus strains (Table 1). Four spectra from each strain were generated by MALDI-TOF-MS and screened for the presence of PVL. Testing these additional strains in our model, five isolates were classified as positive strains and only two of them were later confirmed using molecular methods. Thus, this model exhibited a sensitivity of $100 \%$, a specificity of $90.6 \%$, a PPV of $40 \%$ and a NPV of $100 \%$ 


\section{Discussion}

In the present study, we describe a novel, fast and inexpensive tool for discrimination of $S$. aureus isolates that do or do not produce PVL toxin compared with the actual methods used. Our promising method is based mainly on screening the spectrum profile of $S$. aureus obtained from MALDI-TOF-MS by a model generated using ClinProTools $^{\mathrm{TM}} 2.0$ software. Whilst PCR requires time, technical experience and equipped laboratories, the method described here is very easy and cheap and the analysis can be done within a few minutes.

Our results demonstrate that the peak at $4448 \mathrm{~m} / \mathrm{z}$ was the most relevant peak as it was differentially expressed between $\mathrm{PVL}^{+}$and $\mathrm{PVL}^{-}$strains $(P<0.05)$. Interestingly, the model with only this peak had an overall recognition capability of $100 \%$ and an overall cross-validation of $77.07 \%$. Through this model, two additional cases were detected in $3 \mathrm{~min}$ and before the results of PCR that were obtained during the following $24 \mathrm{~h}$. It is interesting to note that four spectra for each isolate were analysed to confirm the results. The $4448 \mathrm{~m} / \mathrm{z}$ peak was not found in TSST-1-producing $S$. aureus. It will be interesting in the future to see whether other exotoxin-producing $S$. aureus strains share this peak with PVL-associated ones

The predacious infection caused by strains producing PVL and the high mortality (ca. $75 \%$ in the case of necrotizing pneumonia [12]) increase the need for quick detection of such strains. In fact, an appropriate antimicrobial treatment should be administered as soon as possible if a patient is likely to be infected by PVL-associated S. aureus. For example, it has been demonstrated that subinhibitory concentrations of oxacillin, an antibiotic frequently used in the treatment of meticillin-sensitive $S$. aureus, can 
enhance PVL production [13], whilst PVL induction is suppressed with a combination of oxacillin and another antibiotic such as clindamycin, rifampicin or linezolid [13]. Recently it has been demonstrated that protein synthesis inhibitors such as clindamycin can suppress the translation of toxin genes and may have a favourable effect on infections caused by exotoxin-producing S. aureus [14]. On the other hand, intravenous immunoglobulin administration, as an adjunct to antimicrobials, has been found to improve clinically patients with PVL-associated pneumonia $[4,15]$. This latter essential therapy can neutralise pore formation and inhibit the cytopathic effect of PVL toxin [12] that is already produced and present in the lung substance with concomitant tissue damage [4]. Taken together, the high mortality rate of PVLassociated infections and the beneficial effect of early adapted therapy make the time to report results to physicians a critical point as they are likely to change the therapeutic strategy based on the knowledge of whether the strain produces PVL or not. Thus, a rapid method for predicting the presence of PVL toxin could be a critical tool even if the specificity is not $100 \%$.

It is also important that these preliminary results should be expanded and confirmed with more strains obtained from different countries and/or using different conditions of culture and MS instruments.

In conclusion, we demonstrated as a proof of concept that MALDI-TOF-MS is a powerful tool to detect PVL-producing $S$. aureus rapidly. We believe that this methodology could replace conventional methods used in clinical microbiology for rapid identification of bacterial virulence factor and/or antibiotic resistance determinants, allowing changes in therapeutic strategies during time of care. 
Funding: None.

Competing interests: None declared.

Ethical approval: Not required. 


\section{References}

[1] Genestier AL, Michallet MC, Prevost G, Bellot G, Chalabreysse L, Peyrol S, et al. Staphylococcus aureus Panton-Valentine leukocidin directly targets mitochondria and induces Bax-independent apoptosis of human neutrophils. J Clin Invest 2005;115:3117-27.

[2] Labandeira-Rey M, Couzon F, Boisset S, Brown EL, Bes M, Benito Y, et al. Staphylococcus aureus Panton-Valentine leukocidin causes necrotizing pneumonia. Science 2007;315:1130-3.

[3] Iwatsuki K, Yamasaki O, Morizane S, Oono T. Staphylococcal cutaneous infections: invasion, evasion and aggression. J Dermatol Sci 2006;42:203-14.

[4] Morgan MS. Diagnosis and treatment of Panton-Valentine leukocidin (PVL)associated staphylococcal pneumonia. Int J Antimicrob Agents 2007;30:289-96.

[5] Hamilton SM, Bryant AE, Carroll KC, Lockary V, Ma Y, Mclndoo E, et al. In vitro production of Panton-Valentine leukocidin among strains of methicillin-resistant Staphylococcus aureus causing diverse infections. Clin Infect Dis 2007;45:15508.

[6] Oishi K, Baba T, Nakatomi Y, Ito T, Hiramatsu K. A latex agglutination assay for specific detection of Panton-Valentine leukocidin. J Microbiol Methods 2008;75:411-5.

[7] Francois P, Renzi G, Pittet D, Bento M, Lew D, Harbarth S, et al. A novel multiplex real-time PCR assay for rapid typing of major staphylococcal cassette chromosome mec elements. J Clin Microbiol 2004;42:3309-12.

[8] Carbonnelle E, Beretti JL, Cottyn S, Quesne G, Berche P, Nassif X, et al. Rapid identification of staphylococci isolated in clinical microbiology laboratories by 
matrix-assisted laser desorption ionization-time of flight mass spectrometry. $\mathrm{J}$ Clin Microbiol 2007;45:2156-61.

[9] Du Z, Yang R, Guo Z, Song Y, Wang J. Identification of Staphylococcus aureus and determination of its methicillin resistance by matrix-assisted laser desorption/ionization time-of-flight mass spectrometry. Anal Chem 2002;74:548791.

[10] Majcherczyk PA, McKenna T, Moreillon P, Vaudaux P. The discriminatory power of MALDI-TOF mass spectrometry to differentiate between isogenic teicoplanin-susceptible and teicoplanin-resistant strains of methicillin-resistant Staphylococcus aureus. FEMS Microbiol Lett 2006;255:233-9.

[11] Deurenberg RH, Nieuwenhuis RF, Driessen C, London N, Stassen FR, van Tiel FH, et al. The prevalence of the Staphylococcus aureus tst gene among community- and hospital-acquired strains and isolates from Wegener's granulomatosis patients. FEMS Microbiol Lett 2005;245:185-9.

[12] Gauduchon V, Cozon G, Vandenesch F, Genestier AL, Eyssade N, Peyrol S, et al. Neutralization of Staphylococcus aureus Panton Valentine leukocidin by intravenous immunoglobulin in vitro. J Infect Dis 2004;189:346-53.

[13] Dumitrescu O, Badiou C, Bes M, Reverdy ME, Vandenesch F, Etienne J, et al. Effect of antibiotics, alone and in combination, on Panton-Valentine leukocidin production by a Staphylococcus aureus reference strain. Clin Microbiol Infect $2008 ; 14: 384-8$.

[14] Stevens DL, Ma Y, Salmi DB, Mclndoo E, Wallace RJ, Bryant AE. Impact of antibiotics on expression of virulence-associated exotoxin genes in methicillinsensitive and methicillin-resistant Staphylococcus aureus. J Infect Dis 2007;195:202-11. 
[15] Hampson FG, Hancock SW, Primhak RA. Disseminated sepsis due to a Panton-Valentine leukocidin producing strain of community acquired meticillin resistant Staphylococcus aureus and use of intravenous immunoglobulin therapy. Arch Dis Child 2006;91:201. 
Fig. 1. Example of matrix-assisted laser desorption/ionisation time-of-flight (MALDITOF) mass spectra of (A) a Panton-Valentine leukocidin (PVL)-positive strain and (B) a PVL-negative strain between 4000 mass-to-charge ratio $(\mathrm{m} / \mathrm{z})$ and $4800 \mathrm{~m} / \mathrm{z}$.

Fig. 2. (A) Average peaks of Panton-Valentine leukocidin-positive $\left(\mathrm{PVL}^{+}\right)$strains (red) and PVL-negative $\left(\mathrm{PVL}^{-}\right.$) strains (green) between $4000 \mathrm{Da}$ and $5000 \mathrm{Da}$. (B) Calculated average of the peak areas/intensities in $\mathrm{PVL}^{+}$strains (red) and $\mathrm{PVL}^{-}$ strains (green) between $4000 \mathrm{Da}$ and $5000 \mathrm{Da}$. 
Table 1

Strains used in the study

\begin{tabular}{|c|c|c|c|c|c|c|}
\hline Clinical source & Country & $\begin{array}{l}\text { No. of strains } \\
\text { studied }\end{array}$ & $\begin{array}{l}m e c A \\
\text { gene }\end{array}$ & $\begin{array}{l}\text { SCCmec } \\
\text { type }\end{array}$ & $\begin{array}{l}\mathrm{PVL} \\
\text { gene }\end{array}$ & $\begin{array}{l}\text { TSST-1 } \\
\text { gene }\end{array}$ \\
\hline Pus & Algeria & 10 & + & 4 & - & - \\
\hline Pus & Algeria & 22 & + & 5 & - & - \\
\hline Pus & Algeria & 2 & + & $N / D$ & - & - \\
\hline Pus & Algeria & 13 & + & 4 & + & - \\
\hline Venous catheter & Algeria & 2 & + & 4 & - & - \\
\hline Venous catheter & Algeria & 4 & + & 4 & - & - \\
\hline Venous catheter & Algeria & 1 & + & 4 & + & - \\
\hline Blood culture & Algeria & 1 & + & 5 & - & - \\
\hline Blood culture & Algeria & 1 & + & $\mathrm{N} / \mathrm{D}$ & - & - \\
\hline Urine & Algeria & 1 & + & $\mathrm{N} / \mathrm{D}$ & - & - \\
\hline Puncture fluid & Algeria & 2 & + & 4 & - & - \\
\hline Puncture fluid & Algeria & 1 & + & 4 & + & - \\
\hline $\begin{array}{l}\text { Tracheal } \\
\text { aspirate }\end{array}$ & Algeria & 1 & + & 4 & - & - \\
\hline $\begin{array}{l}\text { Tracheal } \\
\text { aspirate }\end{array}$ & Algeria & 1 & + & 5 & - & - \\
\hline $\begin{array}{l}\text { Tracheal } \\
\text { aspirate }\end{array}$ & Algeria & 2 & + & 4 & + & - \\
\hline $\begin{array}{l}\text { Cystic fibrosis } \\
\text { sputum }\end{array}$ & France & 5 & - & $\mathrm{N} / \mathrm{P}$ & - & - \\
\hline $\begin{array}{l}\text { Cystic fibrosis } \\
\text { sputum }\end{array}$ & France & 4 & - & N/P & - & + \\
\hline $\begin{array}{l}\text { Cystic fibrosis } \\
\text { sputum }\end{array}$ & France & 1 & + & 1 & - & + \\
\hline Pleural liquid & France & 1 & + & 4 & + & - \\
\hline Skin biopsy & France & 1 & + & 4 & + & - \\
\hline Bone biopsy & France & 1 & + & 4 & + & - \\
\hline $\begin{array}{l}\text { Pulmonary } \\
\text { biopsy }\end{array}$ & France & 2 & - & N/P & + & - \\
\hline
\end{tabular}




\begin{tabular}{lllllll}
\hline Skin biopsy & France & 2 & - & N/P & + & - \\
Blood culture & France & $2^{a}$ & N/P & N/P & - & N/P \\
Skin biopsy & France & $4^{a}$ & N/P & N/P & - & N/P \\
Skin biopsy & France & $2^{a}$ & N/P & N/P & + & N/P \\
Puncture fluid & France & $3^{a}$ & N/P & N/P & - & N/P \\
Pulmonary & France & $1^{a}$ & N/P & N/P & - & N/P \\
biopsy & & & & & & \\
Venous catheter & France & $1^{a}$ & N/P & N/P & - & N/P \\
Sinus sample & France & $1^{a}$ & N/P & N/P & - & N/P \\
\hline
\end{tabular}

SCCmec, staphylococcal cassette chromosome mec; PVL, Panton-Valentine

leukocidin; TSST-1, toxic shock syndrome toxin; +, positive; -, negative; N/D, not determined (i.e. not SCCmec types 1, 2, 3, 4 or 5); N/P, not performed.

a Strains used in the external validation. 


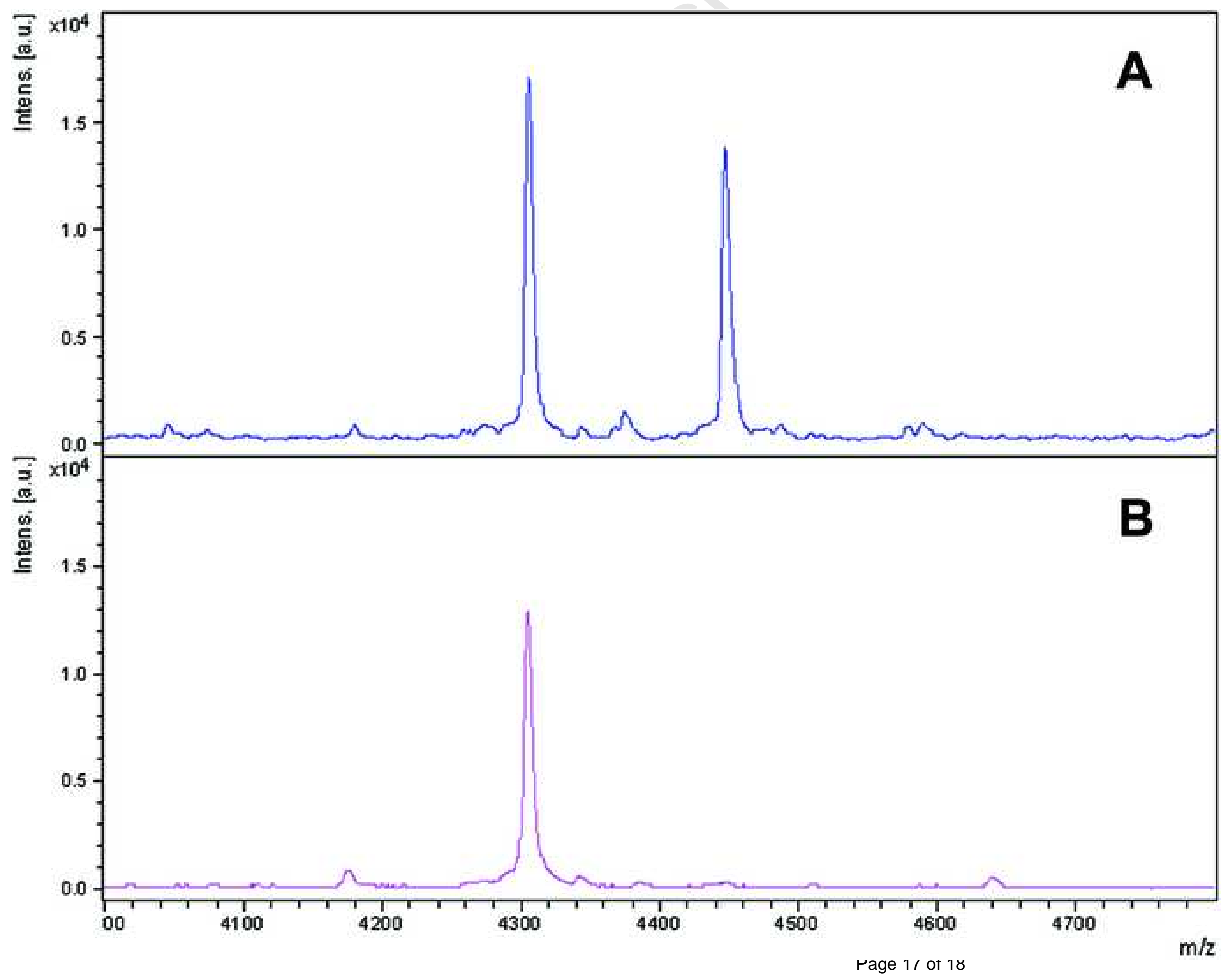



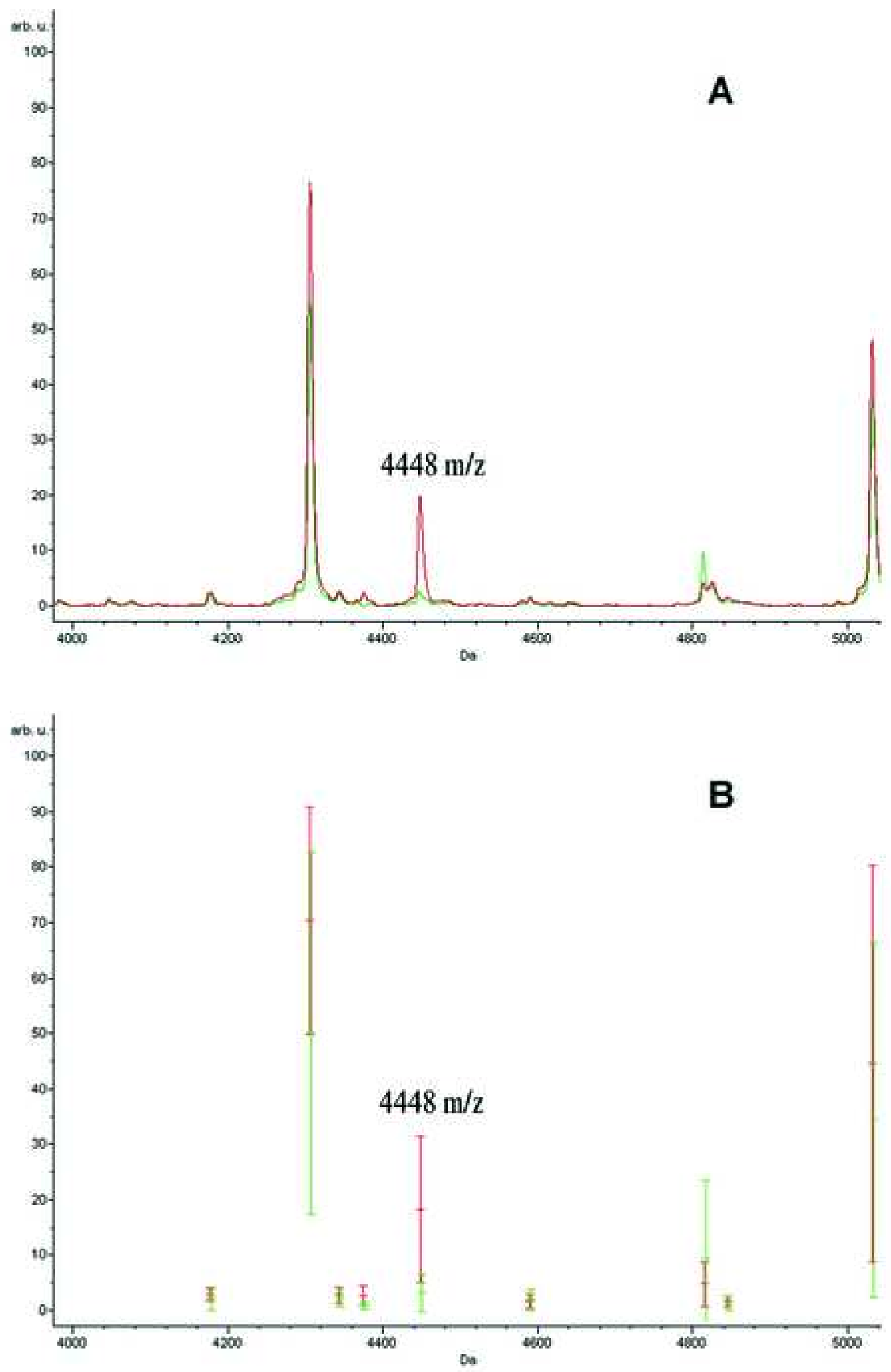

rage 18 of 18 